\title{
Knowledge Creates Markets: The influence of entrepreneurial support and patent rights on academic entrepreneurship
}

\author{
Dirk Czarnitzki $^{\text {a,b }}$, Thorsten Doherr ${ }^{\text {b,c }}$, Katrin Hussinger ${ }^{\text {a,b,c }}$, Paula Schliessler ${ }^{\text {a,b }}$, \\ Andrew A. Toole ${ }^{\mathrm{b}, \mathrm{d}, *}$
}

${ }^{\text {a }}$ KU Leuven, Dept. of Managerial Economics, Strategy and Innovation, Leuven, Belgium

${ }^{\mathrm{b}}$ Centre for European Economic Research (ZEW), Mannheim, Germany

c University of Luxembourg, Luxembourg

${ }^{\mathrm{d}}$ US Patent and Trademark Office, Washington D.C., United States

\section{A R T I C L E I N F O}

\section{Article history:}

Received 8 April 2015

Received in revised form

11 April 2016

Accepted 26 April 2016

Available online 28 April 2016

\section{JEL classification:}

034

038

Keywords:

Intellectual property

Patents

Technology transfer

Policy evaluation

\begin{abstract}
A B S T R A C T
We use an exogenous change in German Federal law to examine how entrepreneurial support and the ownership of patent rights influence academic entrepreneurship. In 2002, the German Federal Government enacted a major reform called Knowledge Creates Markets that set up new infrastructure to facilitate university-industry technology transfer and shifted the ownership of patent rights from university researchers to their universities. Based on a novel researcher-level panel database that includes a control group not affected by the policy change, we find no evidence that the new infrastructure resulted in an increase in start-up companies by university researchers. The shift in patent rights may have strengthened the relationship between patents on university-discovered inventions and university start-ups; however, it substantially decreased the volume of patents with the largest decrease taking place in faculty-firm patenting relationships.
\end{abstract}

Published by Elsevier B.V.

\section{Introduction}

Based on the belief that academic research is an important driver of economic growth and the perception that academic institutions should have an entrepreneurial mission beyond teaching and research, policymakers are increasingly interested in stimulating entrepreneurial behaviors among academic researchers. The idea is to change the incentives researchers face so that entrepreneurial choices are more attractive. Numerous policy levers are available including tax policies, employment policies, subsidies, entrepreneurial education, and intellectual property (IP) policies.

In the area of IP policies, the United States has become the de facto leader. In 1980, the Bayh-Dole Act facilitated institutional ownership of inventions discovered by researchers who were supported by federal funds. Many observers credit the Bayh-Dole Act with spurring university patenting and licensing that, in turn, stimulated innovation and entrepreneurship (The Economist, 2002; OECD, 2003; Stevens, 2004). With this success, the Bayh-Dole Act has become a model of university IP policy that is being debated and emulated in many countries around the world including Germany, Denmark, Japan, China, and others (OECD, 2003; Mowery and Sampat, 2005; So et al., 2008).

\footnotetext{
* Corresponding author at: US Patent and Trademark Office, Washington D.C., United States.
} 
But how do intellectual property rights (IPRs) influence the incentives for university researchers to form start-up companies? Perhaps surprisingly, this question has not received much attention in either the theoretical or empirical literatures. From a theoretical point of view, Damsgaard and Thursby (2013) examined the mode and success of commercialization under an individual ownership system (i.e. the academic inventor keeps the patent rights) and a university ownership system. In a number of cases, their model shows less faculty entrepreneurship (i.e. fewer faculty start-ups) under university ownership. Using survey and case study evidence, Litan et al. (2007) and Kenney and Patton (2009) argued that conflicting objectives and excessive bureaucracy make university ownership ineffective and suggest an individual ownership system may be superior. In a follow-on study looking at technology-based university spin-offs, Kenney and Patton (2011) found suggestive evidence that an individual ownership system is more efficient for generating spin-offs. ${ }^{1}$

In this paper, we use an exogenous change in German Federal law to examine how entrepreneurial support and the ownership of patent rights influence academic entrepreneurship. ${ }^{2}$ The new German policy strengthened the institutional and financial support for academic start-ups and fundamentally changed who owns the patent rights to universitydiscovered inventions. Prior to 2002, university professors and researchers had exclusive intellectual property rights to their inventions. This "Professor's Privilege" allowed university researchers to decide whether or not to patent and how to commercialize their discoveries. After 2002, universities were granted the intellectual property rights to all inventions made by their employees and this shifted the decision to patent from the researchers to the universities.

Based on a novel researcher-level panel database that includes a control group not affected by the IP policy change, we find no evidence that the new infrastructure resulted in an increase in start-up companies by university researchers. The shift of patent rights to the universities not only changed the ownership distribution, but also impacted the volume of patents on university-discovered inventions. The policy reform may have strengthened the relationship between patents on university-discovered inventions and university start-ups (i.e. increased the marginal impact of university-owned patents on university start-ups); however, it substantially decreased the volume of patents with the largest decrease taking place in faculty-firm patenting relationships. By displacing so many faculty-firm relationships, our evidence suggests the policy reform probably decreased overall university technology transfer.

The remainder of the paper is as follows: the next section reviews the German policy reform, develops our conceptual background using the literature and states the hypotheses to be tested. The third section describes the empirical identification strategy and introduces the data. Section 4 discusses the econometric results and the fifth section concludes.

\section{Background and Hypotheses}

In 2002, the German Federal Government introduced a major reform called Knowledge Creates Markets to stimulate technology transfer from universities and other public research organizations to private industry for innovation and economic growth. The program was largely a reaction to the "European paradox" (European Commission, 1995). At that time, policymakers believed that Germany had one of the world's leading scientific research enterprises, but was lagging the United States in terms of technology transfer and commercialization. The new program addressed four broad areas of science-industry interactions including the processes and guidelines governing knowledge transfer, science-based new firms, collaboration, and the exploitation of scientific knowledge in the private sector.

One part of the Knowledge Creates Markets reform created new institutions with new financing to facilitate the movement of university research to the private sector. Unlike most of Germany's public research organizations (PROs), ${ }^{3}$ German universities had little experience undertaking technology transfer activities, and only a few universities maintained professionally managed technology transfer offices (TTOs) (Schmoch et al., 2000). The government established regional patent valorization agencies (PVAs) that were supported with a budget of 46.2 million EURO (Kilger and Bartenbach, 2002). Universities were free to choose whether to use the PVAs' services or not. To date, 29 PVAs serve different regional university networks and employ experts specialized in these universities' research areas. The PVAs support the entire process from screening inventions, finding industry partners, and determining fruitful commercialization paths, including the formation of faculty start-up companies.

While the PVAs were intended to fill a void in the institutional structure supporting commercialization of university research, the reform also called for the expansion of Federal subsidies to university-specific TTOs. Among other initiatives, the legislation included vocational training for university and PRO administrative staff on intellectual property and

\footnotetext{
${ }^{1}$ In a recent working paper, Astebro et al. (2016) compare entrepreneurship between the Bayh-Dole system in the U.S. and Sweden's faculty ownership system. Their analysis finds that Swedish academics are twice as likely to enter entrepreneurship, but average earnings deteriorate for academic entrepreneurs in both countries after founding a new company.

2 Academic entrepreneurship is defined as the formation of a new company in which the university researcher is part of the founding team. This includes all university researcher start-ups - those that license university technologies and those that do not license (Toole and Czarnitzki, 2007; Kenney and Patton, 2011; Czarnitzki et al., 2015).

${ }^{3}$ In addition to universities, Germany's research enterprise includes other public research institutions that have many branches in a variety of different scientific disciplines. For instance, the Fraunhofer Society has 59 institutes in Germany with about 17,000 employees, the Max Planck Society has 76 institutes with about 12,000 employees. The Leibniz Association employs 16,100 people in 86 research centers. The Helmholtz Association has about 30,000 employees in 16 research centers.
} 
innovation management, financial assistance to offset the costs of university patent applications (application and counseling fees), and subsidies for early stage entrepreneurial activity such as business plan development.

The idea that more support services through the PVAs and subsidies to university TTOs could stimulate more technology transfer and academic entrepreneurship finds mixed support in the scholarly literature. One strand of the literature investigates how the presence of a TTO, its resources and its capabilities influence technology transfer indicators such as licenses and spin-off companies. For instance, Siegel et al. (2003) found that the number of TTO staff was positively associated with the number of licensing agreements based on a sample of US universities. For university spin-offs created through licensing, Di Gregorio and Shane (2003) found that specific TTO policies such as inventor royalty rates and the willingness to make equity investments were important. Lockett and Wright (2005) added TTO business development capabilities as a further factor. The development of these capabilities depends on the experience and skill level of the TTO staff (see Grimaldi et al. (2011) and the literature reviews by Rothameral et al. (2007), O'Shea et al. (2008), Bradley et al. (2013) and Kochenkova et al., 2016).

On the other side, several studies identify problems with TTOs as intermediaries, which suggests additional infrastructure and financing may not spur entrepreneurship. Litan et al. (2007) suggest TTOs are misguided due to an overemphasis on revenue maximization and centralization. Kenney and Patton (2009) believe TTOs are ineffective due to bureaucratic problems, informational limitations and misaligned incentives. Using survey data, Siegel et al. (2004) found that $80 \%$ of managers and $70 \%$ of scientists at US research universities cited bureaucracy and inflexibility as barriers. Based on European data, Clarysse et al. (2007) found TTOs play only a marginal, often indirect role, in spurring academics to start new companies.

Although the results in the scholarly literature are mixed, the following hypothesis is based on what policymakers expected:

H1. Infrastructure and financing support provided through the Knowledge Creates Markets reform stimulated university start-up companies

Beyond the infrastructure and financing, the Knowledge Creates Markets reform included one of the most significant changes from both a legal and cultural perspective: the abolishment of Professor's Privilege. Professor's Privilege originated from Article 5 of the German constitution that protects the freedom of science and research. The new program repealed Clause 42 of the German employee invention law that had granted university researchers - as the only occupational group in Germany - the privilege to retain the ownership rights to their inventions that otherwise rest with the employer.

During the Professor's Privilege era most of the responsibility for university technology transfer was in the hands of German professors and patents played an important role. ${ }^{4}$ Patenting provided the legal means for negotiating and partnering with private firms to pursue development and commercialization, especially as most academic discoveries are earlystage or "embryonic" (Colyvas et al., 2002; Jensen and Thursby, 2001). Through this process most German professors gave up their IP to firms, but they also established relationships that involved the exchange of technology with some sort of compensation (pecuniary and/or non-pecuniary). In other words, university-industry technology transfer in Germany had evolved over time into a fairly extensive network of faculty-firm interactions. Presumably most of these relationships were bilateral in the sense that the universities were not legal partners and did not receive any financial compensation.

Also, by owning the patent rights, university researchers could leverage the advantages of patents for creating start-up companies. Hsu and Ziedonis (2013) suggest patents have a "dual function." Beyond knowledge protection, patents may be an important device for reducing asymmetric information and signaling the "quality" of the venture and thus expected returns of the business idea to potential lenders, which provides easier access to finance (Conti et al., 2013; Haeussler and Colyvas, 2011; Graham et al., 2009; Audretsch et al., 2013). Similarly, Shane (2001) argues that patents are disproportionately important to independent entrepreneurs who lack complementary assets. Clarysse et al. (2007) confirm that patents increase the initial funding that university start-ups raise. Levin et al. (1987) state, that "[...] for small, start-up ventures, patents may be a relatively effective means of appropriating R\&D returns, in part because some other means, such as investment in complementary sales and service efforts may not be feasible. The patents held by a small, technologically oriented firm may be its most marketable asset" (Levin et al., 1987, p. 797). ${ }^{5}$

In the current era without Professor's Privilege, German university researchers are required to cull their research findings for inventions and report any inventions to the university - unless the researcher decides to keep his or her inventions secret by not publishing or patenting. The university has four months to consider any submitted inventions for patenting. If the university does not claim the invention, the rights to pursue patenting and commercialization are returned to the researcher. If the university does claim the invention, the inventor receives at least 30\% of the revenues from successful commercialization, but nothing otherwise. Furthermore, the university handles the patenting process and pays all related expenses such as processing fees, translation costs and legal expenses. University researchers retain the right to disclose the

\footnotetext{
${ }^{4}$ University patents are one mechanism for transferring academic research results to the market. Other mechanisms include collaborative and contract research, licensing, networking, publications and so forth (Grimaldi et al., 2011).

${ }^{5}$ A comprehensive investigation of the various expected benefits of patents for technology foundations is conducted by Graham and Sichelman (2008) and Graham et al. (2009). They conclude that protection against imitation and easier access to finance are the main reasons for start-ups to patent (Graham et al., 2009). Other functions of patents of almost an equal importance include an improved likelihood and value of an IPO or acquisition, a stronger reputation, a better negotiation position with other companies, the prevention of IP suits and licensing revenues (Graham et al., 2009).
} 
invention through publication two months after submitting the invention to the university. Prior contractual agreements with third parties also remained valid during a prescribed transition period.

The abolishment of Professor's Privilege created a complex situation regarding the incentives to form start-up companies. It took the initial patenting and commercialization decisions away from the researchers and gave them to the universities. The researcher became secondary to the university TTO in the search, negotiation, partnering with private firms, and forming start-ups. Individual researchers, however, remained the primary decision makers regarding the formation of start-up companies. The critical issue is how the loss of patent rights changed the researchers' costs and benefits associated with the decision to found a start-up company. ${ }^{6}$

University ownership of the patent rights could strengthen the relationship between patents and the formation of startups if, for patented technologies, university ownership lowered "entry" costs for starting a company and/or increased expected returns. This seems to be the outcome German policymakers had in mind. They argued that academic researchers were so resource constrained that the costs of patenting and the market uncertainty surrounding the potential value of discoveries were limiting commercialization. Prior to the reform most patents on university-discovered inventions were owned by private firms. Researchers gave up their patent rights to industry partners as part of a quid-pro-quo, but this meant they lost the opportunity to form start-up companies based on those discoveries. With the university as the primary patent owner, a researcher could regain patent rights if the university does not claim the invention or if the university decides to license the discovery back to the researcher, making it easier for faculty members to found new companies. ${ }^{7}$ Moreover, the university TTOs and regional PVAs perform various kinds of services such as market value assessment before patenting (Debackere and Veugelers, 2005). These services may increase the expected return on a discovery by decreasing the uncertainty about its potential value and thereby stimulate more start-up companies.

H2. The relationship between university start-ups and university owned patents became stronger following the Knowledge Creates Markets reform (i.e. increased the marginal effect of patents on the number of start-ups).

Even if the strength of the relationship between patents and start-ups increased, the effect on the total number of startups depends indirectly on the level of patenting in the post-reform era. Prior work has found the Knowledge Creates Markets reform decreased the volume of patents in university-discovered inventions (Czarnitzki et al., 2015; Von Proff et al., 2012). This effect was primarily due to heterogeneity among university researchers in the costs of patenting, which was reflected in the patent ownership distribution. For instance, under Professor's Privilege, academic researchers who maintained a well-functioning network with industry partners had relatively low costs of patenting by assigning the IPRs directly to industrial partners, but had to forego starting a company on those inventions. After the reform, patenting costs increased as the new university-ownership of the IP disrupted the existing ties between academic inventors and industry (Czarnitzki et al., 2015), but start-ups became a new possibility. Those academic researchers without industry partners had relatively high patenting costs before the reform. Afterward, both the costs of patenting and the costs of starting a company may be lower for these researchers. Overall, the impact of the reform on the formation of researcher start-ups will reflect these two effects. ${ }^{8}$

H3. The net effect of the Knowledge Creates Markets reform on the number of start-ups is determined indirectly by the change in the volume of patents.

\section{Empirical model and data}

\subsection{Identification strategy and estimation approach}

The Knowledge Creates Markets reform provides a unique opportunity to analyze how policy initiatives influence academic entrepreneurship. The changes in technology transfer support and the new IP ownership rules outlined above were targeted primarily at university-discovered inventions. To identify the policy effects, we use a difference-in-difference (DiD) research design with university inventors as the treatment group and PRO researchers as the control group. Like university professors, PRO researchers conduct academic research at publicly funded institutions in Germany. They work in similar

\footnotetext{
${ }^{6}$ This only applies to start-ups that are based on patented technologies. For those that do not rely on patents, the abolishment of Professor's Privilege is irrelevant and any effect of the reform on non-patent start-ups is captured in hypothesis \#1.

7 Hellmann (2007) found this will happen in cases where the researcher is more efficient than the TTO at searching for an industry partner. In his model, a spin-off is an alternative mechanism for organizing the search for an industry partner.

8 Three recent studies use a different framework than we present above, but suggest the net impact of the reform will be fewer spin-offs. Damsgaard and Thursby (2013) consider both regimes using a theoretical model that incorporates the need for continued inventor effort in development. They found the university ownership leads to less entrepreneurship if established firms have some advantage in commercialization. Kenney and Patton (2011) compared inventor versus university ownership using data on technology-based spin-offs from six universities. The University of Waterloo, which was the only university with inventor ownership, matched University of Wisconsin Madison and exceeded the other US universities even though it had less research and development support and fewer faculty members. The authors point to ineffective incentives, information asymmetries, and contradictory goals as the primary reasons university ownership produces fewer spin-offs. Hvide and Jones (2016) found a 50\% decline in faculty start-ups and patenting after the abolishment of Professor's Privilege in Norway.
} 
academic fields and experience similar changes in research opportunities that affect the discovery of new knowledge. But unlike university professors, PRO institutions already had a strong technology transfer infrastructure and the patent rights to the inventions by PRO researchers were always owned by the institution. Our researcher-level DiD setup accounts for common macroeconomic trends and individual-specific unobserved effects that capture an academic inventor's "taste" for patenting and entrepreneurship.

Academic entrepreneurship is measured as the number of firm foundations by academic inventors per year. Note that we deliberately label the dependent variable as start-ups as we will measure all firm foundations by academic inventors in the empirical study and not only those that went through the university (or PRO) TTOs, which are commonly labeled as spinoffs.

$$
E\left(\text { startups }_{i t}\right)=f\left[\beta_{0}+\beta_{1}\left(\operatorname{Prof}_{i} \cdot \text { NewPolicy }_{t}\right)+\sum_{j=1}^{J} \beta_{2 j} \operatorname{Prof}_{i} \cdot \text { NewPolicy }_{t} \cdot P A T_{i j t}+\sum_{j=1}^{J} \beta_{3 j} P A T_{i j t}+\beta_{4} 3 y r A v g P u b s_{i, t-1}+\delta_{i}+\gamma_{t}\right]
$$

The direct impact of the reform is captured by the coefficient $\beta_{1}$ of the interaction term (Prof $\bullet$ NewPolicy). Prof is a dummy variable that takes the value of 1 when the inventor is a university professor and 0 when the inventor is a PRO researcher. NewPolicy $y_{t}$ is a dummy variable that takes the value of 1 following the policy change, 2002 onward, and 0 otherwise. We use a three year moving average of past research publications, $(3 y r A v g P u b s)_{i, t-1}$, to capture the arrival of new knowledge. $\delta_{i}$ is a researcher-level fixed effect and $\gamma_{t}$ is a full set of annual time dummy variables. ${ }^{9}$ Note that the professor dummy variable gets absorbed into the researcher fixed effects. Similarly, the new policy dummy variable gets absorbed by the annual time dummy variables.

In addition to the direct impact of the reform, we are interested in how the abolishment of Professor's Privilege changed the relationship between university start-ups and patents on university-discovered inventions (hypothesis \#2). To test this, we include the variable PAT and its interaction with (Prof•NewPolicy). As the coefficient on PAT shows the strength of the relationship before the reform, a positive and significant coefficient on (Prof •NewPolicy•PAT) would indicate the relationship became stronger.

Notice that Eq. (1) includes summation operators over the index j on the explanatory variable PAT. This index captures ownership types for patented academic inventions. We classified patents on university and PRO-discovered inventions into three ownership types $(J=3)$ : industry, employer institution (university/PRO), and personal (i.e. held by the individual). This was accomplished by manually reviewing the list of applicants and coding the records. Also note, for notational simplicity, we are using the variable PAT to represent patent counts and citation-weighted patents. As will be clear in the discussion of the results, we use citation-weighted patents in some specifications. ${ }^{10}$

In the results section, we present two versions of Eq. (1) in separate tables. First, we look at the overall effect indicated by aggregating all patents and ignoring the variation by ownership type. This will test whether the relationship between startups and patents became stronger overall. In a separate set of regressions, we implement a more flexible specification that estimates separate coefficients for employer-owned (e.g. university) and personal-owned patents in the post-reform period. This allows us to investigate whether the strength of the relationship increased for these ownership types.

Intuitively one might expect that the start-up equation (Eq. (1)) would be modeled as a binary choice. However, a few researchers are involved in multiple firm foundations in some years. Therefore the variable startup becomes a count variable and not a dummy variable. Consequently, we estimate Eq. (1) using a fixed effects Poisson quasi-maximum likelihood estimator (QMLE). As a member of the linear exponential family of distributions, the Poisson QMLE produces consistent estimates of the population parameters as long as the conditional mean is correctly specified (Gouriéroux et al., 1984; Wooldridge, 1999). Consequently, the function $f$ is chosen to be the exponential function in the Poisson regression. We use robust standard errors clustered at the researcher-level. As a robustness test, we also estimate conditional fixed effects logit regressions where the link function is logistic instead of exponential.

It is possible that the number of patents is endogenous in the firm foundation equation. For instance, unobserved market opportunities could influence the decision to found a new firm and be correlated with the decision to seek patent protection. We would like an instrumental variable that influences patent protection, but is unrelated to the market opportunities facing the academic founder. Aggregate patent trends in the United States (US) are attractive instruments because they are arguably exogenous to the firm foundation decision by German academic entrepreneurs, but correlated through broader technology trends. We decided to use the growth rate of US patents by technology class. Higher growth in US patents within a technology area indicates the technology area is increasingly crowded. As more patents crowd a given technology space, costs of patenting exogenously increase. As long as the growth in US patents within technology areas is not related to the error term in the start-up equation for German professors, the IV is exogenous.

\footnotetext{
${ }^{9}$ Note that the literature on life cycle models of researcher productivity often includes career age of the researchers and the square of career age in regression specifications (Diamond, 1986; Levin and Stephan, 1991; Turner and Mairesse, 2005; Hall et al. 2007). As we estimate fixed effects regressions, the model would be fully saturated with the fixed effects, the full set of time dummies and career age. Thus, we do not include the variables career age and its square as regressors; career age is included implicitly by the time dummies in combination with the fixed effects.

${ }^{10}$ We weight patents by the number of citations received over a four year window following application. To avoid dropping patents with zero citations, the citation-weighted patents are constructed as (patents + citations).
} 
We implemented the robust endogeneity test recommended by Wooldridge (2010, p. 742) for count data models. The instrument was constructed using the 35 technology fields according to the Fraunhofer technology classification and linked to each researcher according to his/her main field of activity. The growth rate was defined over the past three years as: [(USPAT $(t)-\operatorname{USPAT}(t-3)) / \operatorname{USPAT}(t-3)]$. For the first-stage regression, which is a linear model with fixed effects, the Fstatistic on the growth of US patents was 13.86, p-value $<0.001$. In the second-stage explaining start-ups, the residuals were insignificant with a $z$-statistic of 0.25 and a $p$-value $=0.803$. Based on these results, we do not consider patent as endogenous in our subsequent models. ${ }^{11}$

As outlined in Section 2, the overall effect of the policy on entrepreneurship also depends on how the reform influenced the volume of patents on university-discovered inventions. To investigate this indirect impact, we follow prior work by Czarnitzki et al. (2015) and use a DiD setup for the volume of academic patents. These DiD models take the form

$$
E\left(\text { PAT }_{i j t}\right)=g\left[\beta_{0}+\beta_{1}\left(\text { Prof }_{i} \cdot \text { New Policy }_{t}\right)+\beta_{2}(3 y r \text { Avg Pubs })_{i, t-1}+\beta_{3} z_{i, t-1}+\delta_{i}+\gamma_{t}\right]
$$

where the notation is as above in Eq. (1) and $z$ stands for the vector of instrumental variables as described above.

As patent counts take only nonnegative integer values, we use the fixed effects Poisson quasi-maximum likelihood estimator (QMLE) again, i.e. the function $g$ is chosen to be the exponential function. We use robust standard errors clustered at the researcher-level.

\subsection{Data and descriptive statistics}

The relevant population of researchers includes academic inventors all who are affiliated with a university or PRO and appeared as an inventor on at least one patent submitted to the German or European Patent Offices between 1978 and 2008. Academic inventors are a subpopulation of all academic researchers in Germany. The broader population includes academic researchers who only published. The core of the Knowledge Creates Markets reform, however, was the abolishment of Professor's Privilege and this did not impact researchers who never participated in the intellectual property system over the entire time period. ${ }^{12}$

We constructed a researcher-level panel dataset of academic inventors following a multistep procedure. In addition, we searched for all of these inventors in the "Mannheim Enterprise Panel," a database containing all German firm foundations and detailed information on the founding persons. The data compilation is summarized in Appendix A. This process yielded a sample with 17,417 university and 35,353 PRO researcher-year observations. ${ }^{13}$ We defined the study period to extend from 1995 through 2008 so that we observed enough time periods before and after the policy change. For each inventor, our data contain the individual's history of patenting between 1978 and 2008 and the individual's history of publications between 1990 and 2008. Each researcher enters the panel when we observe either the first patent application or the first publication. The researcher stays in the panel for a maximum of 35 career years after which we assume the researcher retires. To account for earlier exit, we adopted a 5-year rule that has a researcher leaving the panel if he or she had no patenting or publishing activity for five consecutive years. The estimation sample contains 52,770 researcher-year observations corresponding to 1946 different university researchers and 4551 PRO researchers. ${ }^{14}$

In total, the sample contains 1030 start-ups that were founded between 1995 and 2008 by the researchers in the sample. Thus, most of the 52,770 researcher-year observations in the sample have a value of zero (98.4\%). In some cases, researchers formed more than one start-up in a given year. In the sample, we have 674 observations (1.3\%) where a single start-up was founded by a researcher in a given year; 127 cases $(0.2 \%)$ where two start-ups were formed, and in about $0.05 \%$ of the cases more than two start-ups were formed (with the maximum being five). ${ }^{15}$

Table 1 gives the first indication of how the policy reform influenced academic start-ups and patenting. It shows the number of researcher-founded start-ups, university-discovered and PRO-discovered patented inventions before and after the reform. Looking at the third column, the number of start-ups decreased for university and for PRO researchers after the reform. This is the opposite of what policymakers expected and casts doubt on hypothesis \#1. Column four shows the average annual number of patents decreased for both university discoveries and PRO discoveries. However, the patenting activity of university researchers fell much more dramatically following the reform. This suggests that the abolishment of Professor's Privilege did not stimulate university patenting, however, the strength of the relationship between patenting and start-ups may have increased. This will be investigated in the subsequent econometric models.

\footnotetext{
${ }^{11}$ Note that we experimented also with specifications where we additionally used patent applications at the Japanese Patent Office (JPO) as instrumental variables in addition to the US variable. However, these specifications did not improve or change any result.

12 As noted by a referee, the population of academic researchers who patent is not representative of all academic researchers. The policy reform may have had indirect effects that are not fully captured with our data. One should keep this limitation in mind when interpreting the results.

${ }^{13}$ This sample excludes those researchers who were employed at both a PRO and university, as it is not clear which patent regime applied to these researchers. Furthermore, we had to drop persons with very common German names to ensure clean matches across the patent, publication and firm foundation databases. See Appendix A for more details.

${ }^{14}$ Note that our sample is smaller than the one used by Czarnitzki et al. (2015). This is because we had to drop some common inventor names when linking the inventors to the firm foundation data.

${ }^{15}$ We checked the right tail of the distribution manually and the data are correct. Some exceptional researchers apparently build a small portfolio of different start-up companies at a certain point in their careers.
} 
Table 1

Academic entrepreneurship and patents before and after the 2002 policy reform (annual mean values, 1995-2008).

\begin{tabular}{lll}
\hline & & Start-ups per year \\
\hline University researcher & Before 2002 & 46.43 \\
& After 2002 & 42.57 \\
& & 755.86 \\
PRO researcher & Before 2002 & 29.43 \\
& After 2002 & 28.71 \\
\hline
\end{tabular}

Note: The sample of patenting university researchers comprises 1946 different inventors and the sample of PRO researchers amounts to 4551 people. The 1946 university researchers were, on average, involved in about 46 start-ups and 1312 patents per year before 2002 and these numbers dropped to about 43 start-ups and 1177 patents per year after the law change. The numbers for PRO researchers read equivalently.

Recall the reform was a fundamental change in the ownership structure for university-discovered inventions. Its impact on university start-ups will depend in part on how the ownership distribution on patented university discoveries changed. For instance, when private firms hold the patent rights, researchers have limited opportunities to use these inventions for start-up companies (e.g. industry firms are unlikely to support new companies that may be competitors in their technology space).

Table 2 shows the average number of patents on university-discovered inventions by ownership type before and after the reform. In line prior results reported in Czarnitzki et al. (2015), we see the overall decrease in patented university inventions. Before the policy change, the university inventors filed on average 0.58 patents per researcher per year, and this number drops to 0.34 patents after the policy change (see bottom row labeled "total" in Table 2). For the pre-reform period, the first row shows the extent of faculty-firm bilateral interactions before the reform. Industry applicants owned an average of 0.45 patents per researcher per year. After the shift to university ownership, industry ownership was cut in half to 0.23 on average. This decrease may reflect higher transaction costs after the reform as university TTOs interrupted these bilateral relationships. Even at this much lower level, faculty-firm relationships still accounted for the majority of university-invented patents after the policy change (62\%). Personal-owned patents also fell from 0.14 to 0.04 per researcher per year after the abolishment of Professor's Privilege. In contrast, university-owned patents increased from 0.02 to 0.10 per researcher per year and accounted for $27 \%$ of all patents afterward. The econometric models will show how these ownership changes affected university start-ups.

More detailed descriptive statistics of the sample employed in the following regressions are presented in Appendix B.

\section{Econometric results}

Using the scientist-level DiD research design, we begin with a baseline evaluation of the Knowledge Creates Markets reform. Table 3 shows the regression results explaining the number of university/PRO start-ups using fixed effects Poisson QMLE as well as conditional fixed effects logit regressions. Models 1 and 2 use a count of total patents on academic discoveries while models 3 and 4 use patents weighted by forward citations (a form of quality adjustment).

In the recent applied econometric literature, scholars have raised some doubts about the validity of standard errors in common DiD regressions that estimate treatment effects of policy reforms. Typically relatively long panels are used and the policy reform variable is just a dummy that switches from 0 to 1 for the treatment group and then remains at the value 1 . As this is a regressor that does not vary a lot across the sample observations, scholars have been concerned about biased standard errors, particularly referring to the Moulton bias and to serial correlation problems (Moulton, 1990). Therefore, we conducted a number of robustness tests where we follow the discussions in Bertrand et al. (2004) and Angrist and Pischke (2009). First, we tested for autocorrelation by estimating a linear fixed effects within regression model with AR

Table 2

University-discovered patented inventions by applicant type before and after the 2002 policy reform (mean values, 1995-2008).

\begin{tabular}{lccc}
\hline & Before 2002 & \\
\hline Industry applicant & 0.45 & $74 \%$ & 0.23 \\
Personal applicant & 0.14 & $23 \%$ & 0.04 \\
University applicant & 0.02 & $3 \%$ & 0.10 \\
Sum & 0.61 & $100 \%$ & 0.37 \\
Total & 0.58 & & 0.34 \\
\hline
\end{tabular}

Note: An applicant is equivalent to a US patent assignee. The total row is not the sum of the cells of the columns because some patents are co-applications of different owner types (e.g. industry and personal). In these cases we counted the patent for all owners (instead of applying fractional counting) as each of them maintains unrestricted disposal rights (unless contracts over-ruling the default rights are made). The control group of PRO researchers is omitted here as the law change in 2002 did not apply to them. See the descriptive statistics in Appendix B for more information. 
Table 3

Regressions on academic entrepreneurship (aggregate patents).

\begin{tabular}{|c|c|c|c|c|c|c|c|c|}
\hline \multirow[t]{2}{*}{ Covariates } & \multicolumn{2}{|c|}{$\begin{array}{l}\text { Model } 1 \\
\text { Start-ups }\end{array}$} & \multicolumn{2}{|c|}{$\begin{array}{l}\text { Model } 2 \\
\text { Start-ups }\end{array}$} & \multicolumn{2}{|c|}{$\begin{array}{l}\text { Model } 3 \\
\text { Start-ups }\end{array}$} & \multicolumn{2}{|c|}{$\begin{array}{l}\text { Model } 4 \\
\text { Start-ups }\end{array}$} \\
\hline & Coef. & $\begin{array}{l}\text { Std. } \\
\text { error }\end{array}$ & Coef. & $\begin{array}{l}\text { Std. } \\
\text { error }\end{array}$ & Coef. & $\begin{array}{l}\text { Std. } \\
\text { error }\end{array}$ & Coef. & $\begin{array}{l}\text { Std. } \\
\text { error }\end{array}$ \\
\hline \multicolumn{9}{|l|}{ QMLE Poisson fixed effects regressions } \\
\hline Prof*NewPolicy & -0.036 & 0.174 & -0.006 & 0.180 & -0.032 & 0.175 & -0.012 & 0.180 \\
\hline Patents & 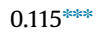 & 0.03 & 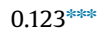 & 0.032 & & & & \\
\hline Prof*NewPolicy*Patents & & & -0.057 & 0.066 & & & & \\
\hline Patents-cited & & & & & $0.042^{* * * *}$ & 0.012 & $0.045^{* * * *}$ & 0.013 \\
\hline Prof*NewPolicy*Patents-cited & & & & & & & -0.025 & 0.029 \\
\hline Avg. Pubs & 0.018 & 0.013 & 0.019 & 0.013 & 0.020 & 0.013 & 0.021 & 0.013 \\
\hline $\begin{array}{l}\text { Test on joint significance of time dummies (Chi-squared } \\
\text { (13)) }\end{array}$ & \multicolumn{2}{|c|}{ 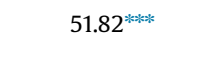 } & \multicolumn{2}{|c|}{$52.28^{* * * * *}$} & \multicolumn{2}{|c|}{$51.73^{* * * *}$} & \multicolumn{2}{|c|}{$51.78^{* * * *}$} \\
\hline Observations & \multicolumn{2}{|c|}{6035} & \multicolumn{2}{|c|}{6035} & \multicolumn{2}{|c|}{6035} & \multicolumn{2}{|c|}{6035} \\
\hline \multicolumn{9}{|l|}{ Conditional fixed effects logit regressions } \\
\hline Prof*NewPolicy & 0.041 & 0.171 & 0.043 & 0.181 & 0.044 & 0.176 & 0.053 & 0.181 \\
\hline Patents & $0.097^{* * * *}$ & 0.030 & $0.098^{* * * *}$ & 0.032 & & & & \\
\hline Prof*NewPolicy*Patents & & & -0.005 & 0.074 & & & & \\
\hline Patents-cited & & & & & $0.033^{* * *}$ & 0.013 & $0.035^{* * *}$ & 0.014 \\
\hline Prof*NewPolicy*Patents-cited & & & & & & & -0.013 & 0.039 \\
\hline Avg. Pubs & $0.024^{*}$ & 0.013 & $0.024^{*}$ & 0.013 & $0.025^{*}$ & 0.013 & $0.025^{*}$ & 0.014 \\
\hline $\begin{array}{l}\text { Test on joint significance of time dummies (Chi-squared } \\
\text { (13)) }\end{array}$ & \multicolumn{2}{|c|}{$66.14^{* * * *}$} & \multicolumn{2}{|c|}{$52.41^{* * * *}$} & \multicolumn{2}{|c|}{$54.07^{* * * *}$} & \multicolumn{2}{|c|}{$58.48^{* * * *}$} \\
\hline Observations & \multicolumn{2}{|c|}{6035} & \multicolumn{2}{|c|}{6035} & \multicolumn{2}{|c|}{6035} & \multicolumn{2}{|c|}{6035} \\
\hline
\end{tabular}

In the case of the Poisson regression, we use cluster-robust standard errors, and for the logit models, we computed cluster-bootstrapped standard errors using 400 replications. Significance:

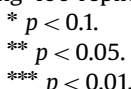

(1) disturbances and calculated the Bhargava et al. (1982) Durbin-Watson tests as well as the Baltagi-Wu (1999) tests. All test were always close to the value 2 , indicating that no auto correlation is present. This is in line with our expectations as start-up creation at the level of the individual researcher is an intermittent activity rather than a persistent one. Furthermore, we calculated cluster-bootstrapped standard errors using 400 bootstrap replications. These were always close to the analytical cluster-robust standard errors. Because of space limitation, we do not show all these numbers. In what follows, the results of the fixed effects Poisson model using analytical cluster-robust standard errors are reported, and for the conditional fixed effects logit models bootstrapped standard errors are shown.

The difference-in-difference regressions in the context of treatment effects estimation are based on the assumption that before the intervention the treatment and the control groups show similar trends in the dependent variable. See Appendix C for a discussion of the common trend assumption. Statistical tests do not reject the hypothesis that the start-up variable shows a common trend in the pre-treatment period for university researchers and PRO researchers.

Turning back to the results in Table 3, policymakers expected the reform to increase the number of start-ups by university researchers due to infrastructure and financing support as stated in hypothesis \#1. Looking across all four models, the variable (Prof*Newpolicy) is not statistically significant in any model. The new PVAs and the additional support for university TTOs did not produce an increase in the number of university researcher start-ups above PRO researcher startups. In fact, from the descriptive statistics in the last section, we saw that start-ups among both groups declined following the reform.

Regarding the abolishment of Professor's Privilege, hypothesis \#2 stated that university ownership could have strengthened the relationship between patents on university-discovered inventions and university start-ups. At least in principle, with university ownership, more patented university-discoveries could be available for start-ups and value-added services by the TTOs could increase the expected returns to forming a start-up. For the models in Table 3, the variables patents and patents-cited capture the marginal effect of patented university discoveries before the Knowledge Creates Markets reform. In all four models (and across both estimation methods), the effect is positive and significant at the $5 \%$ level indicating a strong relationship between patents and start-ups. Looking at Model 1, the marginal effect suggests an additional patent leads to about a $12 \%[\exp (.115)-1]$ increase in the number of university start-ups before the reform. For citation weighted patents, the results in Model 3 are smaller in magnitude, about a 4.4\% increase in start-ups, on average. The marginal effects obtained from the conditional fixed effects logit models are similar in size, yet slightly smaller. The 
post-reform explanatory variables (Prof*Newpolicy*Patents) and (Prof*Newpolicy*Patents-cited) are not statistically significant in any model. Contrary to the prediction in hypothesis $\# 2$, this indicates that the strength of the relationship between patents and start-ups did not get stronger following the reform.

In Table 4, we disaggregate patents into the three ownership types and re-evaluate how the reform changed the strength of the relationship between patents on university-discovered inventions and university start-ups. Looking at the pre-reform relationships in Models 1 and 3, the results are consistent with prior expectations. Patents owned by private firms are not related to university start-ups. Patents held by the researchers' employers (university or PRO) are related to start-ups. This suggests that universities and PROs were somewhat successful at connecting patents to start-ups before the reform. Patents held by the individual researchers (i.e. personal patents) are positive and highly statistically significant. Each additional personal patent in the pre-reform period is associated with about a $34 \%[\exp (.291)-1]$ increase in the number of start-ups (for citation-weighted patents in Model 3 the marginal effect is about 10\%).

But did the Knowledge Creates Markets reform increase the strength of the relationship between patents and start-up activities? Based on the findings in Models 2 and 4, the answer is somewhat mixed. For simple patent counts, Model 2 shows that the reform increased the strength of the relationship for university-owned patents. The coefficient is highly significant at the $1 \%$ level and the suggests each additional patent on university-discovered inventions increases the number of researcher start-ups by about $29 \%[\exp (.254)-1]$, on average. When using citation-weighted patents, however, the coefficient on (Prof*NewPolicy*Employer Patents-cited) is much smaller in magnitude and statistically insignificant. As can be seen in the bottom panel of Table 4, the results for the conditional fixed effects logit models are very similar. This casts some

Table 4

Regressions on academic entrepreneurship (patent ownership type).

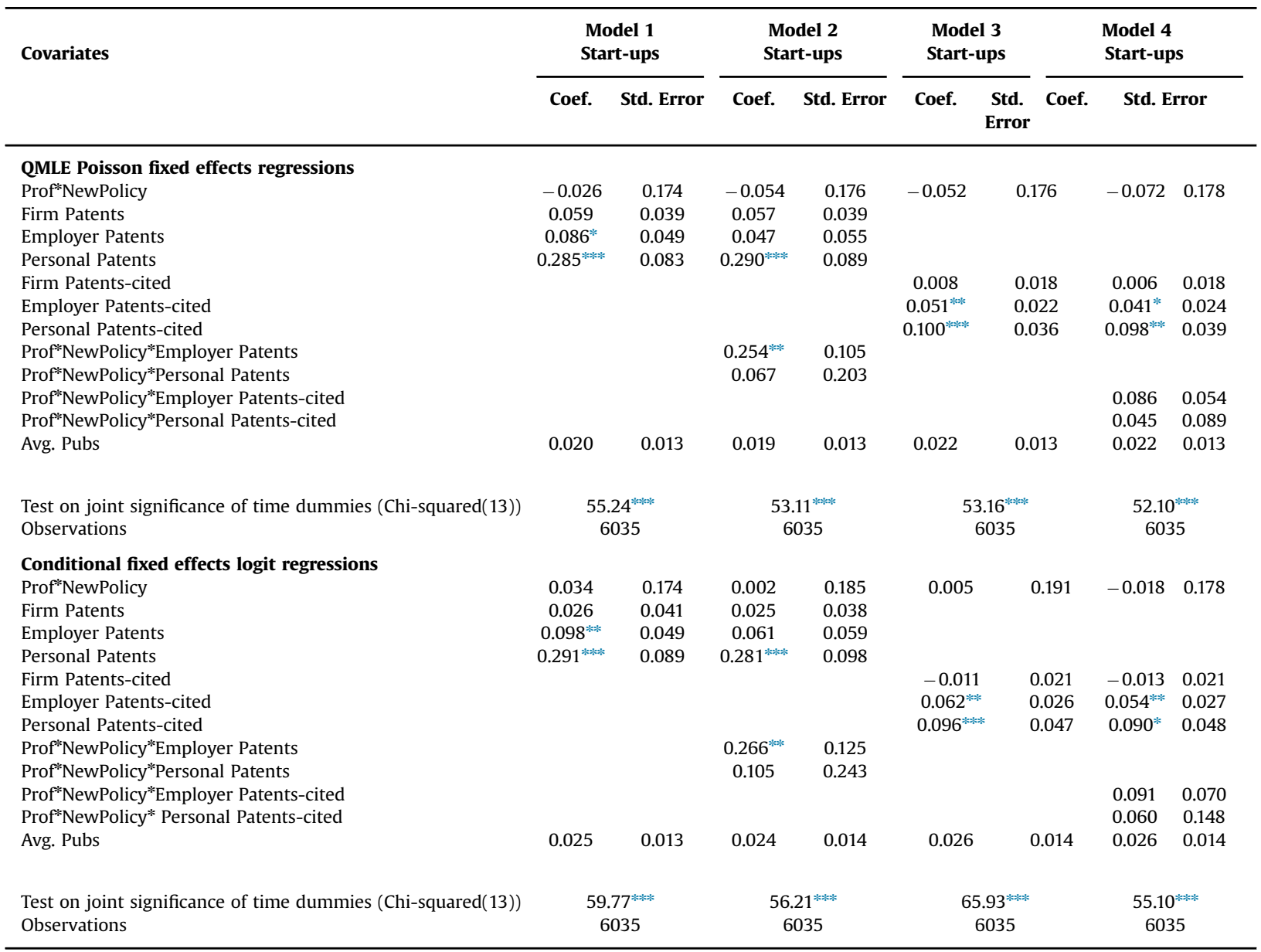

In the case of the Poisson regression, we use cluster-robust standard errors, and for the logit models, we computed cluster-bootstrapped standard errors using 400 replications. Significance:

$$
\begin{aligned}
& * p<0.1 \text {. } \\
& * * *<<0.05 \text {. } \\
& * * * *<0.01 \text {. }
\end{aligned}
$$


Table 5

Poisson models of academic patents (aggregated and by ownership type).

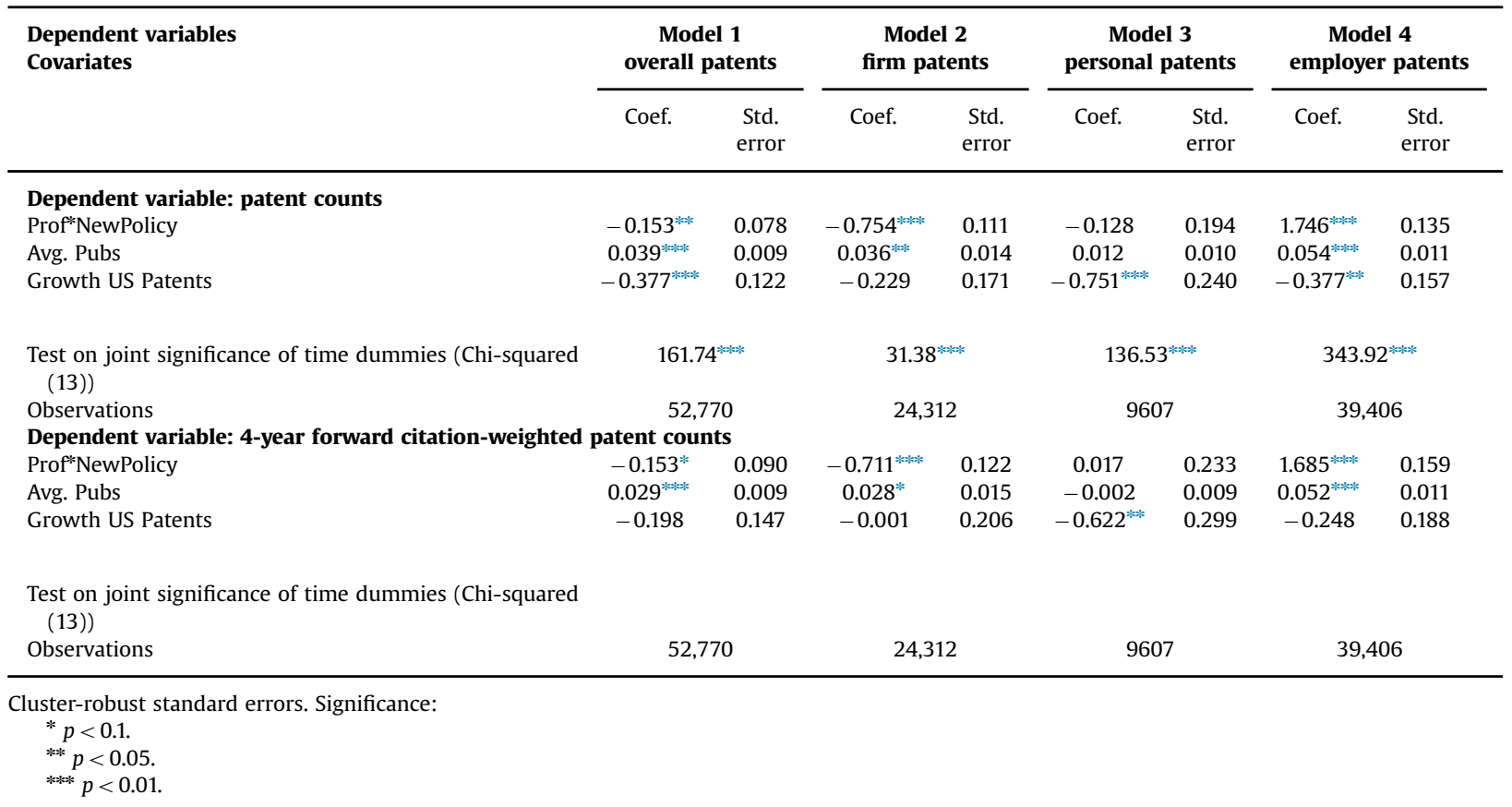

doubt on the robustness of the finding that the reform increased the linkages between patents and start-ups. Citations are intended to be a correction for the quality of the inventions under the idea that a "high quality" invention should attract more follow-on patenting. While standard, this assumption about citation-weighting is quite strong and may actually be correlated with different factors than the market value of the invention or its potential to earn private returns.

It is clear from the results in Tables 3 and 4 that patents on university-discoveries are strongly related to the number of university start-ups, although one may question whether the reform strengthened this relationship. The net impact of the reform on academic entrepreneurship, however, also depends on how the reform affected the volume of patents. To investigate this we start by replicating the main result of Czarnitzki et al. (2015) using Eq. (2) and the smaller sample available for this analysis. Table 5 presents the parameter estimates based on Poisson QMLE with cluster-robust standard errors for patent counts as well as the citation-weighted patent counts. Looking at the upper panel, i.e. at the regressions using patent counts, we find that the overall treatment effect, which is revealed by the coefficient on (Prof•NewPolicy) in Model 1, is negative and statistically significant at the $1 \%$ level. This indicates that the overall effect of abolishing Professor's Privilege was to decrease the volume of patents obtained on university-discovered inventions in Germany. It is economically significant as well. Holding the arrival of new knowledge and other exogenous trend factors constant, the coefficient estimate shows the volume of university patents decreased by about $14 \%[\exp (-.153)-1]$, on average.

Models 2-4 in the upper panel of Table 5 rerun the regression specification in Eq. (2) using the patents by ownership type as alternative dependent variables. In Model 2, firm patents decrease dramatically after the shift to university ownership. The roughly $53 \%[\exp (-.754)-1]$ decrease in the number of patents represents an economically significant decline in technology transfer through faculty-firm relationships. The decrease in personal patents is not significant, but the increase in employer patents due to the shift to university ownership is very large and significant. The point estimate reveals a $473 \%[\exp (1.746)-1]$ increase, albeit from a small starting base. The results suggest that we can expect a lower university start-up rate after the policy change because patents have been shown to be essential for technology start-ups (Graham et al., 2009). The regressions using citation-weighted patent counts in the lower panel of Table 5 show similar results.

\section{Conclusion}

Following the US Bayh-Dole Act in 1980, university ownership became the leading intellectual property model for stimulating university-industry technology transfer for many countries around the world including Germany. In 2001, Germany introduced the Knowledge Creates Markets policy that not only set up new infrastructure and subsidies to support technology transfer, but more fundamentally, it shifted the ownership rights of university-discovered inventions from 
individual researchers to the university. Policymakers hoped to stimulate more patents on university-discoveries with the expectation that increased patenting would allow more licensing and the formation of new start-up companies.

The German policy experiment provides a unique opportunity to learn how academic entrepreneurship responds to policy changes, specifically to greater resources (i.e. infrastructure and subsidies) and to university ownership of IP rights. To identify these effects, we use a difference-in-difference research design with the university researchers as the treatment group and researchers at German public research organizations (PROs) as the control group. Unlike university researchers, PRO researchers already had well established TTOs and the rights to their inventions were already owned by their employing institutions.

The empirical analysis found no impact of the new infrastructure or its associated financing on the number of university start-ups. University start-ups followed the same trends as PRO start-ups after the policy: researchers in both groups of institutions formed fewer start-up companies. Our analysis focuses on the six year period right after the policy change when German TTOs where new at most universities and PVAs were completely new. Some might argue that these institutions lacked the necessary capabilities and routines that are important for fostering academic entrepreneurship (Lockett and Wright, 2005). However, recent studies, including an evaluation report of German PVAs, suggest inefficiencies may be a better explanation for our finding (Cuntz et al., 2012). This is consistent with a growing literature suggesting that intermediaries such as PVAs and TTOs are subject to numerous inefficiencies (e.g. Chapple et al., 2005; Markman et al., 2005; Anderson et al., 2007; Siegel et al., 2004; Kenney and Patton, 2009; Hertzfeld et al., 2006).

We found that the strength of the relationship between patents and start-ups increased (i.e. the marginal effect of patents on start-ups), but only for university-owned patents following the reform and not for citation-weighted patents. As expected, firm-owned patents were not significantly related to faculty start-ups, but personally-owned patent were strongly related to start-ups in the pre-reform period. The post-reform coefficient for personally-owned patents was insignificant, which indicates the relationship did not change due to the policy. This evidence suggests university ownership increases the dependence of academic entrepreneurship on patent protection, but the resulting incentive effects on faculty start-ups remain mixed. On the one hand, patent protection confers advantages to new companies such as signally for financing and the ability to prevent imitation. In principle, this helps spur academic entrepreneurship. On the other hand, the time and money required to obtain patent protection is costly and, at least for some technologies and markets, this may not be necessary. In these cases, a requirement for patent protection could be a bureaucratic barrier that impedes academic entrepreneurship. How these benefits and costs balance out will depend on the specific circumstances facing the academic entrepreneur.

But even if the relationship between patents and start-up activities got stronger, the impact on the number of start-ups still depends on how the number of patents changed as a result of the policy. Consistent with prior work, we found significant decreases in the volume of firm-owned patents, an increase in the volume of university-owned patents, and no change for personally-owned patents. This suggests a trade-off emerged in the modes of technology transfer due to the abolishment of Professor's Privilege. Faculty-firm exchanges decreased dramatically and faculty start-ups increased to some degree. By displacing so many faculty-firm relationships, our evidence suggests the Knowledge Creates Markets reform likely decreased overall university technology transfer, although a final conclusion will need to wait until more research is completed.

For policymakers, our findings highlight the need for careful consideration of the institutional and cultural context before implementing reforms on IP ownership. Too often, the university ownership model is assumed to be the most effective IP policy for spurring academic entrepreneurship and/or other forms of technology transfer. It is important to remember that the Bayh-Dole Act was negotiated to clarify IP ownership for non-governmental US institutions within the US cultural environment. For Germany, in the era of Professor's Privilege, IP ownership rights were clearly delineated and privately held. Our evidence suggests the network of faculty-firm relationships in place prior to the Knowledge Creates Markets reform was disrupted without compensating benefits. It appears the value and extent of this network was poorly investigated at the time of the reform. One clear lesson is for policymakers to require more background research and information before adopting IP ownership reforms.

Our study is not free of limitations. It will be important in future research to examine the performance of university startup companies to better understand how these policies affected the economic impact of academic entrepreneurship. Entrepreneurial support and the ownership of patent rights might change the economic contribution of university start-ups by altering the "quality" distribution of these new companies, which may be observable using firm sales or employment data. Furthermore, our inferences about technology transfer are based on patents and start-ups. A more inclusive analysis would add indicators such as licensing, contracting agreements, material transfers, and other less formal arrangements. For this, researchers will need to develop new databases. Overall, these limitations point to new opportunities for research as policymakers need information on how to structure IP ownership rules for greater innovation and growth.

\section{Acknowledgments}

We are grateful for the funding of this research project by the Centre for European Economic Research (ZEW) within the research program "Strengthening Efficiency and Competitiveness in the European Knowledge Economies" (SEEK). The views 
expressed in this article are the authors' and do not necessarily represent the views of the United States Patent and Trademark Office.

\section{Appendix A. Data collection procedure}

Our data process starts with all patent applications filed at the German Patent and Trademark Office (DPMA) and the European Patent Office (EPO) involving at least one German inventor since 1978 using the PATSTAT database. We collapse the list of relevant patent documents to the number of inventions to account for patent families. Between 1995 and 2008 (our sample period) the total number of patent families is 624,041. Based on our data process, German professors and PRO researchers appear as inventors on 58,252 patent families (9.3\% of all patent families). Among those, 18,253 refer to professor-invented patent families.

\section{Searching patents invented by university faculty}

As no comprehensive list of German university faculty members exists, we followed an alternative strategy that has been used in prior research to identify patents of university professors (see e.g. Czarnitzki et al. (2007, 2009)). In Germany, the award of a doctorate and holding a professorial position are considered great honors. The "Dr." becomes an official part of one's name and is, for example, even mentioned in the national IDs and passports. The professor title is protected by the German criminal code (article 132a) against misuse by unauthorized persons. Accordingly this title is used as a name affix not only in academic environment, but also in daily life. Based on this, we search the inventor records in the database for the title "Prof. Dr." and a large number of variations of this. ${ }^{16}$ After having obtained an initial list of patent documents, we also searched for these inventors again in order to see whether they also patented without the "Prof. Dr." title. Note that we do not claim to have identified all university invented patents, but it is certainly a large share of this population. Our numbers are close to those reported in policy documents circulated during the debate on Professor's Privilege in the late 1990s. Those documents said that university-invented patents accounted for about $4 \%$ of all German invented patents. This is an intermediate data preparation step. The list of patent documents will be disambiguated in a subsequent step to identify the number of patenting professors.

\section{Identifying patents by $P R O$ researchers}

The identification of patents by PRO scientists is more straightforward because they can be searched by institution (i.e. applicant) names. The intellectual property rights to inventions made by their researchers were always owned by the institutional. We obtained a list of about 500 PRO institutes existing in Germany from the "Bundesbericht Forschung und Innovation 2012" published by the federal government. These institutional were searched as applicants in the patent documents. In order to create a list of unique PRO inventors, we select all patents on this list that have the PRO as only applicant. These are 70\% of all PRO patents. This was necessary to avoid including industry researchers is our data. Next we searched for all patents by these inventors again, in order to come up with a comprehensive list of patents filed by PRO inventors.

\section{Disambiguation routine}

The two lists of retained patent documents were pooled. This merged list may include too many patents, because of name homonyms. In addition, some inventors may switch between the two groups of institutions and thus appear in both lists. Therefore, we then implemented a disambiguation routine leading to a list of unique inventors.

The disambiguation algorithm is based on a relation network analysis. Every node within this network is a patent connected to other patents by layers of relations defined by shared applicants, co-inventors, citations and joint sets of IPC codes. The analysis uses a hierarchical approach by first traversing connections of high reliability to define sub-clusters that function as new nodes for the next iterative step. By aggregating information within these 'hypernodes' new connections emerge that will also be traversed and so on. As every sub-cluster describes a part of an inventor career, suspiciously large sub-clusters can easily be identified, rejected and re-traversed with more restrictive requirements for the connections. This method implicitly solves the common name problem. The resulting list of unique individuals and their corresponding patents has been checked manually to the largest extent possible.

Some of the professors also appear as PRO researchers at some point in time. We exclude those researchers associated with both institutions from the regressions reported in the main body of the text. By doing so, we omit those researchers for whom we do not know which IP policy is binding, the policy of the university or the policy of the PRO.

\footnotetext{
16 One may be concerned that the Professor Doctor title is also given as an honorary title to individuals who are not employed at universities. While the granting of honorary titles seems to be relatively rare, some of these highly qualified individuals may be labeled as professors in our data process. We believe any misclassification error would work against finding a significant policy effect as these individuals are not affected by the policy change.
} 
The list of inventors is used to perform name searches in the Thomson Reuters Web of Science publication database, 1990-2008. We first retrieve all publications from Web of Science that match with respect to the names in our inventor list and have at least one German affiliation. This amounts to 572,936 publications. Second, we disambiguate these authors from Web of Science using cross-referencing information on journals, coauthors, citations and affiliations. Out of the almost 600,000 possible publications, 296,320 are identified as being authored by the inventors in our sample from 1995 to 2008 (the publication data from 1990 to 1994 was only taken into account in order to improve the name disambiguation routine and are not part of our final sample).

\section{Compiling the panel database}

The final step of the database construction involves generating a panel of unique academic inventors that includes information on their patents, citation-weighted patents and publications for each year. We count patents at the family level to ensure that patents in different jurisdictions for the same invention are not counted more than once. The unit of observation is a researcher-year. We restrict the regression sample period to run from 1995 through 2008. However, we keep those researchers who patented before 1995 in the sample. This implies that a researcher does not need to have a patent in the 1995 to 2008 period to be in the sample. We define entry into research as the year the researcher first appeared as an inventor on a patent or as an author on a journal publication. The final database is an unbalanced panel.

Adding the firm foundation data to the panel

In order to add firm foundation data to the panel we matched the names and associated cities of the researchers (professors and PRO researchers) to the owners, founder and major stakeholders of firms located in Germany. We use the Mannheim Enterprise panel database for this exercise. It is a panel data set of firms located in Germany. It is maintained at ZEW in cooperation with Creditreform, the largest business information service in Germany. Creditreform sends its firm data in six-month intervals to ZEW, where the data is cleaned and prepared as to panel database, the Mannheim Enterprise Panel ("MUP"). The MUP enables the analysis of, for example, market entrances and exits (start-ups and shut-downs), changes in numbers of economically active firms in specific sectors and regions, the development of firms over time or the dynamics of job creation in firms. Among other information, it includes the names of all founders and other shareholders. We use this information to match start-ups to our academic inventor data.

The match is based on name and associated cities of the researchers. We exclude those researchers that have matches in the firm database based on their name, but not on city as we cannot be certain that they are involved in a firm or not. We keep those with matches based on name and city and those for which no firm foundation entry is found. Note that this essentially means that researchers with very common German names are dropped. This reduces the number of observations in the database for this paper to 52,770 researcher-year observations (1995-2008) with 830 researcher-year observations associated with one or more start-ups per year. The 52,770 researcher-year observations are based on 1946 different university researchers and 4551 different PRO researchers.

\section{Appendix B. Regression descriptive statistics}

The following tables present the descriptive statistics of the variables used in the regression models for both university researchers and PRO researchers before and after the policy change in 2002. The variable PAT denotes all patents. This is subsequently split to the different ownership types, i.e. FIRM indicates firm ownership; EMPL stands for the employer of the scientist owning the patent which could be either the university of the public research organization for the control group; and PERS denotes patents that are owned by persons. The term CIT then denotes the patent counts weighted by citations these patents received in the 4 years following the patent application.

The variable US_PAT denotes the total number of patent applications at the US Patent and Trademark Office in the technology field of the corresponding researcher. We experimented with several specifications in the regression model and finally do not use the level of US patents but their three-year growth rate, i.e. GR_US_PAT=(US_PAT $t-$ US_PAT $\left._{t-3}\right)$ / $\mathrm{US}_{-} \mathrm{PAT}_{t-3}$.

Table B1 is here. 
Table B1

Descriptive statistics.

\begin{tabular}{|c|c|c|c|c|c|c|c|c|}
\hline \multirow[t]{3}{*}{ Variable } & \multicolumn{8}{|c|}{ University researchers } \\
\hline & \multicolumn{4}{|c|}{ Before 2002 reform $(N=9180)$} & \multicolumn{4}{|c|}{ After 2002 reform $(N=8237)$} \\
\hline & Mean & Std. Dev. & Min & Max & Mean & Std. Dev. & Min & Max \\
\hline STARTUP & 0.04 & 0.23 & 0 & 5.00 & 0.04 & 0.23 & 0 & 4.00 \\
\hline PAT & 0.58 & 1.41 & 0 & 24.00 & 0.34 & 1.03 & 0 & 28.00 \\
\hline PAT_FIRM & 0.45 & 1.34 & 0 & 24.00 & 0.23 & 0.96 & 0 & 28.00 \\
\hline PAT_EMPL & 0.02 & 0.19 & 0 & 4.00 & 0.10 & 0.39 & 0 & 6.00 \\
\hline PAT_PERS & 0.14 & 0.51 & 0 & 10.00 & 0.04 & 0.24 & 0 & 5.00 \\
\hline PAT_CIT & 0.97 & 2.79 & 0 & 62.00 & 0.52 & 1.85 & 0 & 56.00 \\
\hline PAT_CIT_FIRM & 0.76 & 2.65 & 0 & 62.00 & 0.36 & 1.74 & 0 & 56.00 \\
\hline PAT_CIT_EMPL & 0.04 & 0.38 & 0 & 17.00 & 0.13 & 0.63 & 0 & 15.00 \\
\hline PAT_CIT_PERS & 0.24 & 1.05 & 0 & 26.00 & 0.06 & 0.45 & 0 & 13.00 \\
\hline 3 yr avg. pubs & 2.38 & 4.87 & 0 & 67.33 & 3.22 & 6.22 & 0 & 73.33 \\
\hline \multirow[t]{3}{*}{ GR_US_PAT } & 0.28 & 0.22 & -0.19 & 1.00 & 0.29 & 0.17 & -0.21 & 0.85 \\
\hline & \multicolumn{8}{|c|}{ PRO researchers } \\
\hline & \multicolumn{4}{|c|}{ Before 2002 reform $(N=15,507)$} & \multicolumn{4}{|c|}{ After 2002 reform $(N=19,846)$} \\
\hline STARTUP & 0.01 & 0.14 & 0 & 4.00 & 0.01 & 0.12 & 0 & 4.00 \\
\hline PAT & 0.56 & 1.27 & 0 & 29.00 & 0.40 & 1.07 & 0 & 26.00 \\
\hline PAT_FIRM & 0.21 & 0.98 & 0 & 29.00 & 0.16 & 0.90 & 0 & 26.00 \\
\hline PAT_EMPL & 0.39 & 0.91 & 0 & 16.00 & 0.28 & 0.71 & 0 & 17.00 \\
\hline PAT_PERS & 0.02 & 0.21 & 0 & 9.00 & 0.01 & 0.09 & 0 & 4.00 \\
\hline PAT_CIT & 0.97 & 2.58 & 0 & 61.00 & 0.62 & 1.91 & 0 & 51.00 \\
\hline PAT_CIT_FIRM & 0.37 & 1.96 & 0 & 61.00 & 0.26 & 1.58 & 0 & 51.00 \\
\hline PAT_CIT_EMPL & 0.67 & 1.85 & 0 & 42.00 & 0.43 & 1.32 & 0 & 28.00 \\
\hline PAT_CIT_PERS & 0.05 & 0.48 & 0 & 22.00 & 0.01 & 0.16 & 0 & 11.00 \\
\hline 3 yr avg. pubs & 0.87 & 2.11 & 0 & 44.00 & 1.12 & 2.46 & 0 & 63.67 \\
\hline GR_US_PAT & 0.27 & 0.20 & -0.19 & 1.00 & 0.28 & 0.18 & -0.21 & 0.85 \\
\hline
\end{tabular}

\section{Appendix C. Trend graphs}

Fig. C1 shows the pre-treatment and post-treatment trends of the start-up variable. Note that the depicted variables are the averages of the within-demeaned dependent variable of the regressions presented in Tables 3 and 4 . A visual inspection may suggest that the pre-treatment trends in the period 1998/1999 differ between treatment and control group. Note, however, the scale of the vertical axis: the numerical differences are tiny. When implementing a formal test on whether the pre-treatment trends differ among the groups, the common trend assumption was never rejected at the $5 \%$ significance level. We implemented the test by annual t-tests on significant differences in the change of start-ups in first differences, and

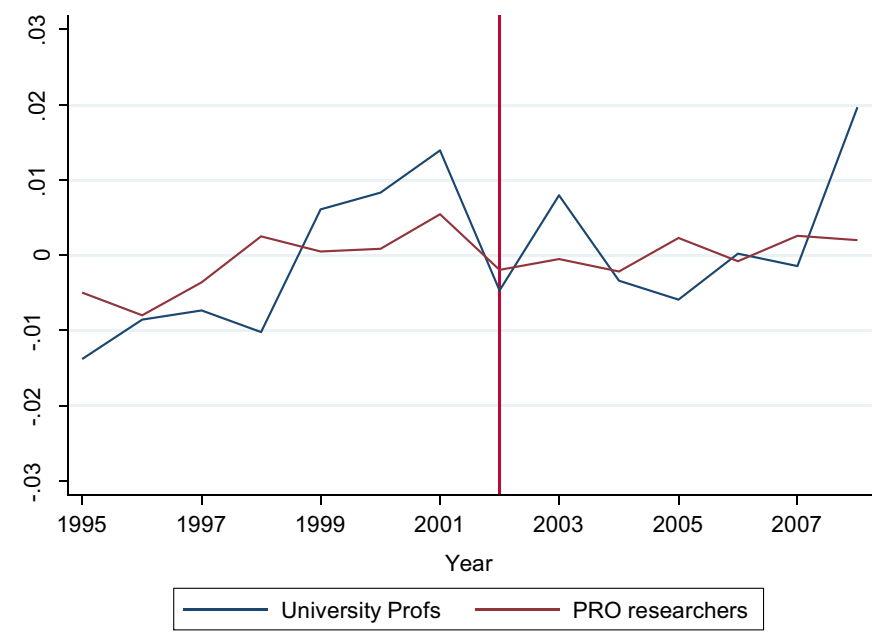

Fig. C1. Average trends of start-up activity. 
also conducted a joint test in a regression on first differences of the start-up variable. The $F$-statistic on the test whether the annual slopes are jointly different only amounts to $F=0.99$ with a $p$-value of 0.43 .

\section{References}

Anderson, T.R., Tugrul, U.D., Lavoie, F.F., 2007. Measuring the efficiency of university technology transfer. Technovation 27 (5), $306-318$. Angrist, J.D., Pischke, J.S., 2009. In: Mostly Harmless Econometrics: An Empiricist's CompanionPrinceton University Press, Princeton.

Astebro, T., Braguinsky, S., Braunerhjelm, P., Brostrom, A., 2016. Bayh-Dole versus the Professor's Privilege. HEC Paris, Mimeo.

Audretsch, D.B., Leyden, D.P., Link, A.N., 2013. Regional appropriation of university-based knowledge and technology for economic development. Econ. Dev. Q. 27 (1), 56-61.

Baltagi, B.H., Wu, P.X., 1999. Unequally spaced panel data regressions with AR(1) disturbances. Econom. Theory 15, 814-823.

Bertrand, M., Duflo, E., Mullainathan, S., 2004. How much should we trust differences-in-differences estimates? Q. J. Econ. 119 (1), $249-275$.

Bhargava, A., Franzini, L., Narendranathan, W., 1982. Serial correlation and the fixed effects model. Rev. Econ. Stud. 49, 533-549.

Bradley, S.R., Hayter, C.S., Link, A.N., 2013. Models and methods of university technology transfer. Found. Trends Entrep. 9 (6), 571-650.

Chapple, W., Lockett, A., Siegel, D., Wright, M., 2005. Assessing the relative performance of U.K. university technology transfer offices: parametric and nonparametric evidence. Res. Policy 34 (3), 369-384.

Clarysse, B., Wright, M., Lockett, A., Mustar, P., Knockaert, M., 2007. Academic spin-offs, formal technology transfer and capital raising. Ind. Corp. Change 16 (4), 609-640.

Colyvas, J., Crow, M., Gelijns, A., Mazzoleni, R., Nelson, R.R., Rosenberg, N., Sampat, B.N., 2002. How do university inventions get into practice? Manag. Sci. $48(1), 61-72$.

Conti, A., Thursby, J.C., Thursby, M.C., 2013. Patents as Signals for Startup Financing. NBER, Cambridge, MA.

Cuntz, A., Dauchert, H., Meurer, P., Philipps, A., 2012. Hochschulpatente zehn Jahre nach Abschaffung des Hochschullehrerprivilegs. Studien zum deutschen Innovationssystem 13-2012, Berlin.

Czarnitzki, D., Doherr, T., Hussinger, K., Schliessler, P., Toole, A., 2015. Individual Versus University Ownership of University-discovered Inventions. ZEW Discussion Paper 15-007. Mannheim.

Czarnitzki, D., Glänzel, W., Hussinger, K., 2007. Patent and publication activities of German professors: an empirical assessment of their co-activity. Res. Eval. 16 (4), 311-319.

Czarnitzki, D., Glänzel, W., Hussinger, K., 2009. Heterogeneity of patenting activity and its implications for scientific research. Res. Policy 38, 26-34.

Damsgaard, E.F., Thursby, M.C., 2013. University entrepreneurship and professor Privilege. Ind. and Corp. Change 22 (1), 183-218.

Debackere, K., Veugelers, R., 2005. The role of academic technology transfer organizations in improving industry science links. Res. Policy 34 (3), $321-342$.

Di Gregorio, D., Shane, S., 2003. Why do some universities generate more start-ups than others? Res. Policy 32 (2), 209-227.

Diamond, A.M., 1986. The life-cycle research productivity of mathematicians and scientists. Journal. Gerontol. 41 (4), 520-525.

European Commission, 1995. Green Paper on Innovation. Brussels.

Gouriéroux, C., Montfort, A., Trognon, A., 1984. Pseudo maximum likelihood methods: application to poisson models. Econometrica 52 (3), $701-721$.

Graham, J.H.S., Sichelman, T., 2008. Why do start-ups patent? Berkeley Technol. Law J. 23 (3), 1063-1097.

Graham, J.H.S., Merges, R., Samuelson, P., Sichelman, T., 2009. High technology entrepreneurs and the patent system: results of the 2008 Berkeley patent survey. Berkeley Technol. Law J. 24 (4), 255-327.

Grimaldi, R., Kenney, D., Siegel, D.S., Wright, M., 2011. 30 years after Bayh-Dole: Reassessing academic entrepreneurship. Res. Policy 40 (8), $1045-1057$.

Haeussler, C., Colyvas, J.A., 2011. Breaking the ivory tower: Academic entrepreneurship in the life sciences in UK and Germany. Res. Policy 40 (1), $41-54$.

Hall, B.H., Mairesse, J., Turner, L., 2007. Identifying age, cohort and period effects in scientific research productivity: Discussion and illustration using simulated and actual data on French physicists. Econ. Innov. New Technol. 16 (2), 159-177.

Hellmann, T., 2007. The role of patents for bridging the science to market gap. J. Econ. Behav. Organ. 63, 624-647.

Hertzfeld, H.R., Link, A.N., Vonortas, N.S., 2006. Intellectual property protection mechanisms in research partnerships. Res. Policy 35 (6), $825-838$.

Hsu, D.H., Ziedonis, R.H., 2013. Resources as dual sources of advantage: implications for valuing entrepreneurial-firm patents. Strateg. Manag. J. 34 (7), 761-781.

Hvide, H., Jones, B., 2016. University Innovation and the Professor's Privilege. University of Bergen Discussion Paper in Economics No 16-1.

Jensen, R., Thursby, M., 2001. Proofs and prototypes for sale: The licensing of university inventions. Am. Econ. Rev. 91 (1), 240-259.

Kenney, M., Patton, D., 2009. Reconsidering the Bayh-Dole act and the current university invention ownership model. Res. Policy 38, 1407-1422.

Kenney, M., Patton, D., 2011. Does inventor ownership encourage university research-derived entrepreneurship? A six university comparison. Res. Policy 40 (8), 1100-1112.

Kilger, C., Bartenbach, K., 2002. New rules for German professors. Science 298 (5596), 1173-1175.

Kochenkova, A., Grimaldi, R., Munari, N., 2016. Public policy measures in support of knowledge transfer activities: a review of academic literature. J. Technol. Transf. (Forthcoming).

Levin, R.C., Klevorick, A.K., Nelson, R.R., Winter, S.G., Gilbert, R., Griliches, Z., 1987. Appropriating the returns from industrial research and development. Brookings Pap. Econ. Act. 1987 (3), 783-831.

Levin, S.G., Stephan, P.E., 1991. Research productivity over the life cycle: evidence for academic scientists. Am. Econ. Rev. 81 (1), 114-132.

Litan, R., Mitchell, L., Reedy, R., 2007. Commercializing university innovations: alternative approaches. In: Jaffe, A., Lerner, J., Stern, S. (Eds.), Innovation Policy and the Economy, University of Chicago Press, Chicago, IL, pp. 31-58.

Lockett, A., Wright, M., 2005. Resources, capabilities, risk capital and the creation of university spin-out companies. Res. Policy 34 (7), $1043-1057$.

Markman, G.D., Phan, P.H., Balkin, D.B., Gianiodis, P.T., 2005. Entrepreneurship and university-based technology transfer. J. Bus. Ventur. 20 (2), $241-263$.

Moulton, B.R., 1990. An illustration of a pitfall in estimating the effects of aggregate variables in micro units. Rev. Econ. Stat. 72 (2), $334-338$.

Mowery, D.C., Sampat, B.N., 2005. The Bayh-Dole Act of 1980 and university-industry technology transfer: A model for other OECD governments? J. Technol. Transf. 30 (1/2), 115-127.

OECD, 2003. In: Turning Science Into Business: Patenting and Licensing at Public Research OrganizationsOECD, Paris.

O'Shea, R.P., Chugh, H., Allen, T.J., 2008. Determinants and consequences of university spinoff activity: a conceptual framework. J. Technol. Transf. 33 (6), 653-666.

Rothameral, F.T., Agung, S.D., Jiang, L., 2007. University entrepreneurship: a taxonomy of the literature. Ind. Corp. Change 16 (4), $691-791$.

Schmoch, U., Licht, G., Reinhard, M., 2000. In: Wissens- und Technologietransfer in DeutschlandFraunhofer IRB Verlag, Stuttgart.

Siegel, D.S., Waldman, D., Link, A., 2003. Assessing the impact of organizational practices on the relative productivity of university technology transfer offices: an exploratory study. Res. Policy 32, 27-38.

Siegel, D.S., Waldman, D.A., Atwater, L.E., Link, A.N., 2004. Toward a model of the effective transfer of scientific knowledge from academicians to practitioners: qualitative evidence from the commercialization of university technologies. J. Eng. Technol. Manag. 21, 115-142.

Shane, S., 2001. Technology regimes in new firm formation. Manag. Sci. 47 (9), 1173-1190.

So, A.D., Sampat, B.N., Rai, A.K., Cook-Deegan, R., Reichman, J.H., Weissman, R., Kapczynski, A., 2008. Is Bayh-Dole good for developing countries? Lessons from the US Experience. PLoS Biol. 6 (10), 2078-2084.

Stevens, A., 2004. The enactment of Bayh-Dole. J. Technol. Transf. 29, 93-99. 
The Economist, 2002. Innovation's golden goose - The reforms that unleashed American innovation in the 1980s, and were emulated widely around the world, are under attack at hom. Technology Quarterly, Q4 2002.

Toole, A.A., Czarnitzki, D., 2007. Biomedical academic entrepreneurship through the SBIR program. J. Econ. Behav. Organ. 63 (4), 716-738.

Turner, L., Mairesse, J., 2005. Individual productivity differences in public research: How important are non-individual determinants? An econometric study of French physicists' publications and citations (1986-1997). 〈http://piketty.pse.ens.fr/fichiers/Turner2005.pdf), (Retrieved 02.11.15).

Wooldridge, J., 1999. Distribution-free estimation of some nonlinear panel data models. J. Econom. 90 (1), 77-97.

Wooldridge, J.M., 2010. Econometric Analysis of Cross Section and Panel Data. The MIT Press, Cambridge, MA. 